Received: 26 May 2017

Accepted: 10 August 2017

Published online: 30 August 2017

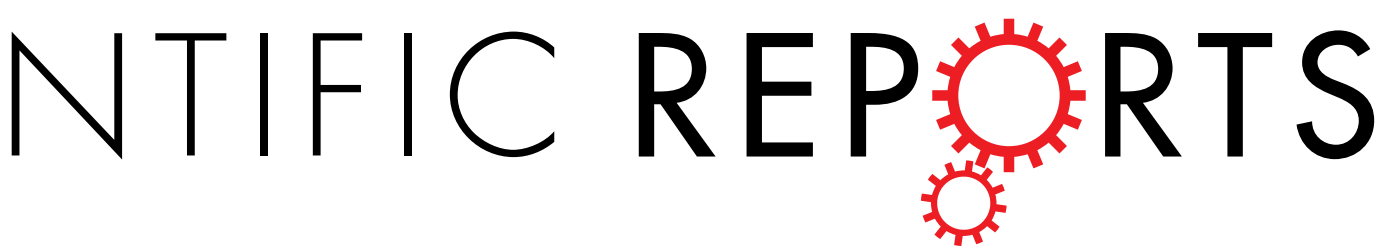

\title{
Source apportionment of VOCs and their impacts on surface ozone in an industry city of Baoji, Northwestern China
}

\author{
Yonggang Xue ${ }^{1,2}$, Steven Sai Hang $\mathrm{Ho}^{1,2,3}$, Yu Huang $\mathbb{D}^{1,2}$, Bowei $\mathrm{Li}^{1,4}$, Liqin Wang ${ }^{1,2}$, \\ Wenting Dai ${ }^{1,2}$, Junji Cao ${ }^{1,2}$ \& Shuncheng Lee ${ }^{5}$
}

Level of surface ozone $\left(\mathrm{O}_{3}\right)$ has been increasing continuously in China in recent years, while its contributors and formation pathways are less understood. In this study, distributions of volatile organic compounds ( $\mathrm{VOCs}$ ) and the roles on $\mathrm{O}_{3}$ pollution have been investigated in a typical industrial city of Baoji in Northwestern China by means of monitoring of their concentrations and other trace gases. The air samples have been collected at three sites according to urban function area. Concentration of VOCs in Weibin site, which near to industrial zone, was higher than most of other cities in China, and the ambient VOCs were dominated by aromatics and alkenes. The temporal variations of VOCs and $\mathrm{O}_{3}$ coincided with the surface wind, implying that the formation of $\mathrm{O}_{3}$ was impacted by both exports of plumes upwind and local photochemical reactions. Result of source apportionment indicated that industrial emission, vehicular exhaust, and solvent evaporation were three major pollution origins. Alkenes and aromatics contributed to the largest fractions of photochemical reactivity, suggesting the strong influences from industrial and traffic sectors. The study presents the characteristic VOCs and other factors in the contribution of $\mathrm{O}_{3}$ formation in China.

Ozone $\left(\mathrm{O}_{3}\right)$ is important constituent of the atmosphere, the concentration of ozone mostly decreases from stratosphere to surface ground downward ${ }^{1}$. Surface or tropospheric $\mathrm{O}_{3}$ originated mainly from regular transportation from stratosphere ${ }^{2}$, direct emissions in source-dominated regions ${ }^{3}$, and photochemical reactions between volatile organic compounds (VOCs) and nitrogen oxides $\left(\mathrm{NO}_{\mathrm{x}}\right)^{4,5}$. In between, photochemistry plays an important role on both sources and sinks of $\mathrm{O}_{3}$, subjected to the atmospheric $\mathrm{NO}_{\mathrm{x}}$ levels ${ }^{4,6}$. Xue et al. ${ }^{3}$ reported that the in-situ photochemical production is the main source for the surface $\mathrm{O}_{3}$ in megacities in China based on calculations with observation-based model. In urban site, the mixing ratio of $\mathrm{NO}_{\mathrm{x}}$ is often high (up to $70 \mathrm{ppbv}$ ) due to large quantities of emissions from heavy industries and vehicular engines. The $\mathrm{O}_{3}$ budget is thus sensitive to photochemical reactivity of VOCs and $\mathrm{NO}_{\mathrm{x}}{ }^{3,7-9}$. Under short term regulatory measures, reduction of anthropogenic VOCs emission is efficient in shrinking of $\mathrm{O}_{3}$ peak. However, the approaches only lead the reaction mechanism between VOCs- $\mathrm{NO}_{\mathrm{x}}-\mathrm{O}_{3}$ transferred from $\mathrm{NO}_{\mathrm{x}}$-dependent to VOCs-dependent while VOCs becomes a limiting factor, in the case of no decline of $\mathrm{NO}_{x}$ emission. Instead, to further reduce surface $\mathrm{O}_{3}$ level, regulations on both VOCs, biogenic VOCs (BVOCs) and $\mathrm{NO}_{\mathrm{x}}$ are needed in a long term run ${ }^{9}$.

Understanding of the sources of VOCs is a base for $\mathrm{O}_{3}$ pollution control. Common anthropogenic activities include coal burning from industrial and residential uses, vehicle exhausts, gasoline volatilization, solvent use, petrochemical manufacturing and biomass burning ${ }^{10-17}$. In addition, biogenic source, in particular of vegetation emission, is a vital factor in VOCs budget ${ }^{18-20}$. Source apportionments of VOCs in ambient environments are always deployed with receptor models, like positive matrix factorization (PMF), chemical mass balance (CMB),

${ }^{1}$ Key Lab of Aerosol Chemistry \& Physics, Institute of Earth Environment, Chinese Academy of Sciences, Xi'an, 710061, China. ${ }^{2}$ State Key Lab of Loess and Quaternary Geology (SKLLQG), Institute of Earth Environment, Chinese Academy of Sciences, Xi'an, 710061, China. ${ }^{3}$ Division of Atmospheric Sciences, Desert Research Institute, Reno, Nevada, USA. ${ }^{4}$ School of Human Settlements and Civil Engineering, Xi'an Jiaotong University, Xi'an, 710049, China. ${ }^{5}$ Department of Civil and Environmental Engineering, The Hong Kong Polytechnic University, Hung Hom, Hong Kong. Correspondence and requests for materials should be addressed to Y.H. (email: huangyu@ieecas.cn) or J.C. (email: cao@loess.llqg.ac.cn) 


\begin{tabular}{|c|c|c|c|c|c|c|c|c|c|c|c|}
\hline & & Alkane & $\%$ & Alkene & $\%$ & Aromatic & $\%$ & Isoprene & $\%$ & TVOCs $_{\text {PAMS }}$ & Reference \\
\hline \multirow{3}{*}{ Baoji } & $\begin{array}{l}\text { Weibin site } \\
\text { (urban) }\end{array}$ & $14.00 \pm 5.00$ & 29.2 & $8.84 \pm 4.16$ & 18.4 & $24.49 \pm 11.36$ & 51.0 & $0.78 \pm 0.28$ & 1.62 & $48.03 \pm 18.15$ & \multirow{3}{*}{$\begin{array}{l}\text { The present } \\
\text { study }\end{array}$} \\
\hline & $\begin{array}{l}\text { Chencang site } \\
\text { (suburban) }\end{array}$ & $10.63 \pm 6.88$ & 62.5 & $1.81 \pm 2.58$ & 10.6 & $4.46 \pm 3.32$ & 26.2 & $0.59 \pm 0.52$ & 3.47 & $17.00 \pm 11.36$ & \\
\hline & $\begin{array}{l}\text { Miaogou site } \\
\text { (rural) }\end{array}$ & $9.67 \pm 5.40$ & 56.0 & $1.23 \pm 1.86$ & 7.1 & $5.56 \pm 4.32$ & 32.2 & $0.95 \pm 0.75$ & 5.50 & $17.27 \pm 10.18$ & \\
\hline Beijing & Urban & $15.50 \pm 2.00$ & 42.6 & $4.40 \pm 1.10$ & 12.1 & $8.60 \pm 1.20$ & 23.6 & $0.70-0.80$ & 1.92 & $36.4 \pm 12.1$ & $\begin{array}{l}\text { Shao et al. } \\
(2009)\end{array}$ \\
\hline Guangzhou & Suburban & $20.72 \pm 1.43$ & 56.0 & $7.49 \pm 1.42$ & 18.5 & $12.37 \pm 2.17$ & 30.5 & 1.10 & 2.71 & $40.58 \pm 0.89$ & $\begin{array}{l}\text { Zou, Y et al. } \\
\text { (2015) }\end{array}$ \\
\hline Hong Kong & Urban & 32.67 & 71.3 & 7.05 & 15.4 & 6.11 & 13.3 & 0.25 & 0.55 & 45.83 & $\begin{array}{l}\text { Huang et al. } \\
\text { (2015) }\end{array}$ \\
\hline
\end{tabular}

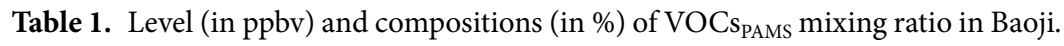

and UNMIX ${ }^{21-23}$. In Northern China (e.g., Beijing), the atmospheric VOCs were mainly influenced by combustions of coal, gasoline, petrochemicals, and compressed natural gas (CNG), while solvent use and biogenic sources also had minor contributions ${ }^{24-26}$. However, solvent use was the major source contributor reported in Pearl River Delta (PRD) region in China, where influenced by the emissions from a large number of factories (e.g., dye and shoemaking factories in Guangdong province) ${ }^{27,28}$.

Fine particle and ground-level $\mathrm{O}_{3}$ are the causes for severe air pollutions, which pose high health risk as well ${ }^{29-31}$. In the recent years, the surface $\mathrm{O}_{3}$ level has been continuously increasing in most Chinese cities ${ }^{32}$. In northern region, the concentration in rural site had an increasing rate of $1.13 \pm 0.01$ ppbv year $^{-1}$ from 2003 to $2015^{32}$, comparing with 0.87 ppbv year $^{-1}$ from 2001 to 2007 at a background station in Hong Kong, where is located in Southern $\mathrm{China}^{33}$. And in the urban site, it was found that surface $\mathrm{O}_{3}$ increased as rate of $1.1 \pm 0.5$ ppbv year $^{-1}$ in the city of Beijing between 2001-2006 ${ }^{34}$, while in the city of Hong Kong, surface $\mathrm{O}_{3}$ increase as a rate $0.5-0.8$ from mid 1960s to $2010^{35}$.

Baoji is an industrial city in the western edge of Guanzhong basin, and was in Shaanxi province in Northwestern China. The main industries include power plants, coal chemical industry, metal smelting, and coke productions ${ }^{36}$. The consumption of coal from industry sector is about ten millions tons annually (from the official statistic collected by Baoji Municipal Environmental Protection Bureau, not published yet). And the emissions plumes from both industry and traffic emissions can highly impact the air quality and elevate the surface $\mathrm{O}_{3}$ pollution to downwind regions ${ }^{5,37-39}$. In summer, the mixing ratios of surface $\mathrm{O}_{3}$ in Baoji increased with ambient temperature and radiation. Its hour-average exceeded the China National Standard of $160 \mu \mathrm{g} \mathrm{m}^{-3}$ in a frequency of 9 to 14 days per month from May to August in 2016 (https://www.aqistudy.cn/). Ozone is the dominant factor in air pollution (https://www.aqistudy.cn/). Either speciation or evaluation of VOCs was sparsely conducted in Northwestern China ${ }^{40}$, and no any data were even reported in Baoji. A one-week simultaneous observation was used to evaluate the levels and compositions of both VOCs and $\mathrm{O}_{3}$ in this industrial city in summer, 2016. This study aims to investigate the impacts of VOCs emissions on the pollution in this typical industrial city. The Photochemical Assessment Monitoring Stations (PAMS) organized by United States Environmental Protection Agency (U.S.EPA) had defined 57 critical ozone precursors $\left(\right.$ VOCs $_{\text {PAMS }}{ }^{26}$. A total number of 57 VOCs that contributed mostly on the $\mathrm{O}_{3}$ formation in atmosphere were quantified ${ }^{41}$. Temporal variation and potential pollution sources were identified. The correlations among the levels of $\mathrm{VOCs}_{\mathrm{PAMS}}$ and $\mathrm{NO}_{\mathrm{x}}$ and meteorological factors contributed in the $\mathrm{O}_{3}$ formation at different locations were discussed.

\section{Results and Discussion}

Characterization of VOCs. Table 1 summarizes the mixing ratios of different classes of VOCs PAMS $_{\text {quan- }}$ tified at the three sites (the mixing ratios of individual compound were listed in Table S1). Isoprene is classified separately from alkenes to evaluate its strong indication from biogenic sources. The average mixing ratios of total quantified VOCs PAMS $_{\text {(TVOCs }}$ (TAMS) were $48.03 \pm 18.15,17.00 \pm 11.36,17.27 \pm 10.18$ ppbv measured in the Weibin, Chencang and Miaogou sites, respectively. Comparing to the ambient levels in the Chinese megacities, our VOCs $s_{\text {PAMS }}$ in Weibin site were higher than those in Beijing in summer of 2005 (36.4 \pm 12.1 ppbv), but close to Southern regions such as Guangzhou ( $40.58 \pm 0.89 \mathrm{ppbv})$ and Hong Kong ( $45.83 \mathrm{ppbv}$ ) where influenced by industrial and traffic emissions in major ${ }^{7,8,23}$.

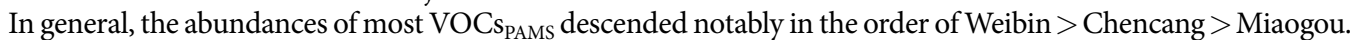

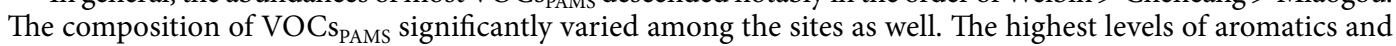
alkenes were observed in the Weibin site, with the mixing ratios of $16.6 \pm 8.0$ and $7.7 \pm 4.5 \mathrm{ppbv}$, respectively. The high abundances can be ascribed to the existence of fossil fuel combustion sources installed in the industries nearby the site ${ }^{10,42}$. Particularly, aromatics had a molar contribution of $51.0 \%$ of TVOCs $_{\text {PAMS }}$ in the Weibin site (Table 1). Benzene, the most abundant aromatic in the samples of Weibin site, is an well-known tracer for the emissions of coal, biomass burning, and automobile ${ }^{42}$. Propene was the next abundant compound, followed by undecane, 2-methylhexane, toluene, and iso-pentane. This distribution was consistent with the emission profiles of metal smelt, coke production and power plants, which were located at the upwind position of the Weibin site ${ }^{27}$. The result also implies that the strong impacts from combustion sources such as industrial coal burning and vehicular emission. In comparison with the Weibin site, lower mixing ratio of benzene was measured in the Chencang site, $\mathrm{C}_{2}-\mathrm{C}_{5}$ alkenes, $\mathrm{C}_{2}-\mathrm{C}_{5}$ alkanes, $\mathrm{C}_{10}-\mathrm{C}_{12}$ alkanes and xylenes were higher than other VOCs $\mathrm{PAMS}_{\text {, }}$, where the VOCs PAMs $_{\text {profile repre- }}$ sents the more dominance of traffic-related sources ${ }^{10,23}$. This finding was relatable to the facts that the Chencang 
site was next to two highways (Lian-huo highway and Bao-han highway) and less factories nearby. At the Miaogou

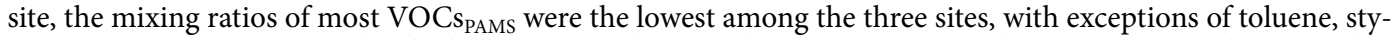
rene, undecane, isoprene, and p-diethylbenzene. Toluene and styrene are universal components in solvents used in manufactures ${ }^{43}$, while $\mathrm{C}_{9}-\mathrm{C}_{12}$ alkanes and isoprene are tracers for diesel exhaust and biogenic sources, respectively ${ }^{10,18}$.

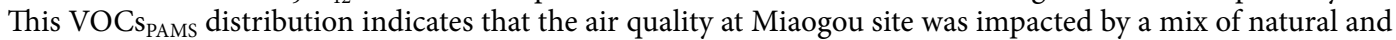
anthropogenic pollution sources. Scattered small-scale paint factories presented around the site in the on-site survey, and the plants in the forests can contribute greatly on the biogenic emissions ${ }^{10,43}$.

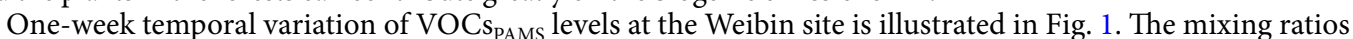
of TVOCs PAMS $_{\text {in Weibin site varied with surface wind directions. Higher mixing ratios of VOCs }}$ PAMS were shown on the sampling days of June 16, June 17 and June 19, when the dominant wind was easterly (Figure S1). Dense power plants, metal smelt, coke production and coal chemical industries were located in the eastern and northeastern regions of Baoji. The high-frequency easterly surface winds could thus bring up those discharged pollutants to the downwind locations. The consequent effects can be also reflected on the significant elevation of corresponding marker species such as benzene and propene. In addition, from the time series, the highest

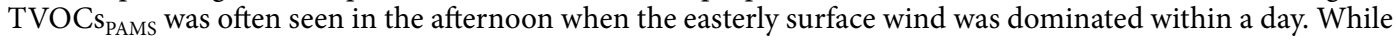

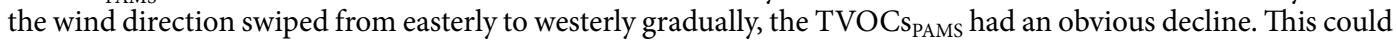
also demonstrate the strong impact from the industrial emissions.

Correlation between VOCs species. Correlation analysis between individual VOCs PAMS $_{\text {compound was }}$ used to interpret the potential and dominant pollution sources ${ }^{31}$. Propane and $n$-butane are important VOCs from vehicular emissions, and their correlation acts a useful indicator for traffic contribution ${ }^{10,31}$. In the current study, propane was well-correlated with $n$-butane at both sites $\left(0.82<R^{2}<0.87\right)$, with slopes of $0.51,0.37$, and 0.49 for the Weibin site, Chencang and Miaogou, respectively (Fig. 2a). The ratios of $n$-butane/propane were close to that reported in a tunnel study $(\sim 0.5)^{10}$, demonstrating the inalienable input from vehicular emission in Baoji. The regressions of aromatics and long-chain alkanes (e.g., $\mathrm{C}_{8}-\mathrm{C}_{12}$ ) varied significantly among the sampling sites, appointing to a wide variety of source contributions (Fig. 2c, Table S2). In the Weibin site, toluene was highly correlated $\left(R^{2}=0.50-0.95\right)$ with other aromatics (e.g., ethylbenzene, xylenes, and styrene) and $n$-decane $\left(R^{2}=0.65\right)$ but fairly to poorly with undecane and dodecane $\left(R^{2}=0.29\right.$ and 0.47 , respectively). Reversibly, good correlations $\left(R^{2}>0.65\right)$ between benzene and the long-chain alkanes (except $n$-decane with an $\left.R^{2}=0.22\right)$ were found. Benzene was also correlated poorly with ethylbenzene, xylenes, and styrene $\left(R^{2}=0.24-0.29\right)$ (Table S2). Benzene

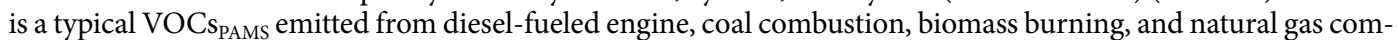
bustion $^{10,42,44-46}$, while gasoline-fueled engine emission, paint production, printing, and other solvent involved activities release more toluene, ethylbenzene, xylene and styrene in composition ${ }^{10,43}$. Those correlations not only prove the high contribution of combustion sources in the Weibin site, and also suggest that the ambient levels of toluene, ethylbenzene, xylenes, styrene, 1,3,5-trimethylbenzene and $n$-decane might be additionally elevated by solvent-related industries ${ }^{10,47}$. Figure $2 \mathrm{~b}$ presents the correlations between toluene and benzene varied from Weibin site to Miaogou site. In the Weibin site, the mixing ratio of benzene was far higher than toluene (slope of toluene verse benzene $=0.05$ ), ascribed to the strong benzene emissions from the local factories and transportation from the industrial zone with the easterly wind. In contrast to the Weibin site, the mixing ratios of toluene, styrene and dodecane were unexpectedly high in the Miaogou site. This also indicates that the solvent involved manufacture processes in the scattered paint and printing factories had a large contribution to the emissions of toluene and other aromatics ${ }^{43}$.

The molar ratio of xylenes ( $m$-/ $p$-isomers) and ethylbenzene is often used to access the air mass aging, considering that the differences in degradation rates [i.e., hydroxyl $\left(\mathrm{OH}^{\bullet}\right)$ reaction coefficients $\left(K_{O H}\right)$ ], in which xylenes have higher $K_{\mathrm{OH}}$ of $1.36-2.30 \times 10^{-11}$ in comparison of lower $K_{\mathrm{OH}}$ of $7.0 \times 10^{-12}$ for ethylbenzene ${ }^{31,48,49}$. In this study, the ratios of xylenes to ethylbenzene were both high at the Weibin site and Chencang sites (1.84 and 2.03, respectively, Fig. 3d), attribute to the fresh emissions from the pollution sources. However, a much low average ratio was found in the Miaogou site (0.42), additionally with a poor correlation between the two chemicals $\left(R^{2}=0.10\right)$. It is reasonable that relatively more aged air mass in Miaogou region due to its geographical posi-

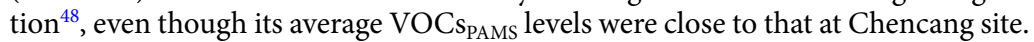

Source apportionment of VOCs $s_{\text {PAMS. }}$ Source apportionment was conducted with PMF receptor model.

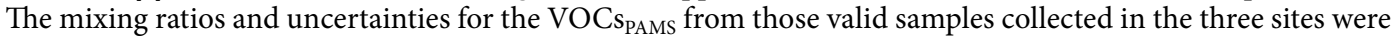
used. Calibration was run for 3-7 factors and with random seeds. The seven factors solution produced mathematical [(Q values (both robust and true) close to the theoretical Q value] with reasonable explanation. The results are illustrated in Fig. 3. In Factor 1, it has high loadings of benzene, propylene, 1-butene and 1-pentene in a descending order in mixing ratios, that was close to the profile of coal combustion emissions ${ }^{10}$. Factor 2 is filled with propane, $\mathrm{n}$-butane, $\mathrm{n}$-pentane, iso-pentane and toluene. Most of these $\mathrm{VOC}_{\mathrm{PAMS}}$ were relevant to the fuel evaporation, in particular of gasoline and CNG. Factor 3 is characterized by n-decane, undecane, xylenes, ethylbenzene, 1,2,3-trimethylbenzene, 1,2,4-trimethylbenzene, p-diethylbenzene, 3-methylpentane, ethylene, 1-pentene. The composite was corresponding to and dominated by the diesel-fuel combustion ${ }^{10}$. However, it must be noted that 3-methylpentane, a common marker for gasoline exhaust, was unexpectedly high in this factor. Even though the major contribution of Factor 3 could be characterized by the diesel combustion, the gasoline emission might still contribute a few. Factor 4 is consistent with a typical gasoline exhaust profile. Factor 5 is singly filled with high abundance of iso-butane but no representative source could be identified, thus is marked as others. Factor 6 is

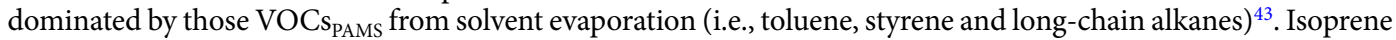
is the major component in vegetation emission, even it is always detected in the vehicle exhaust ${ }^{10}$. Considering 

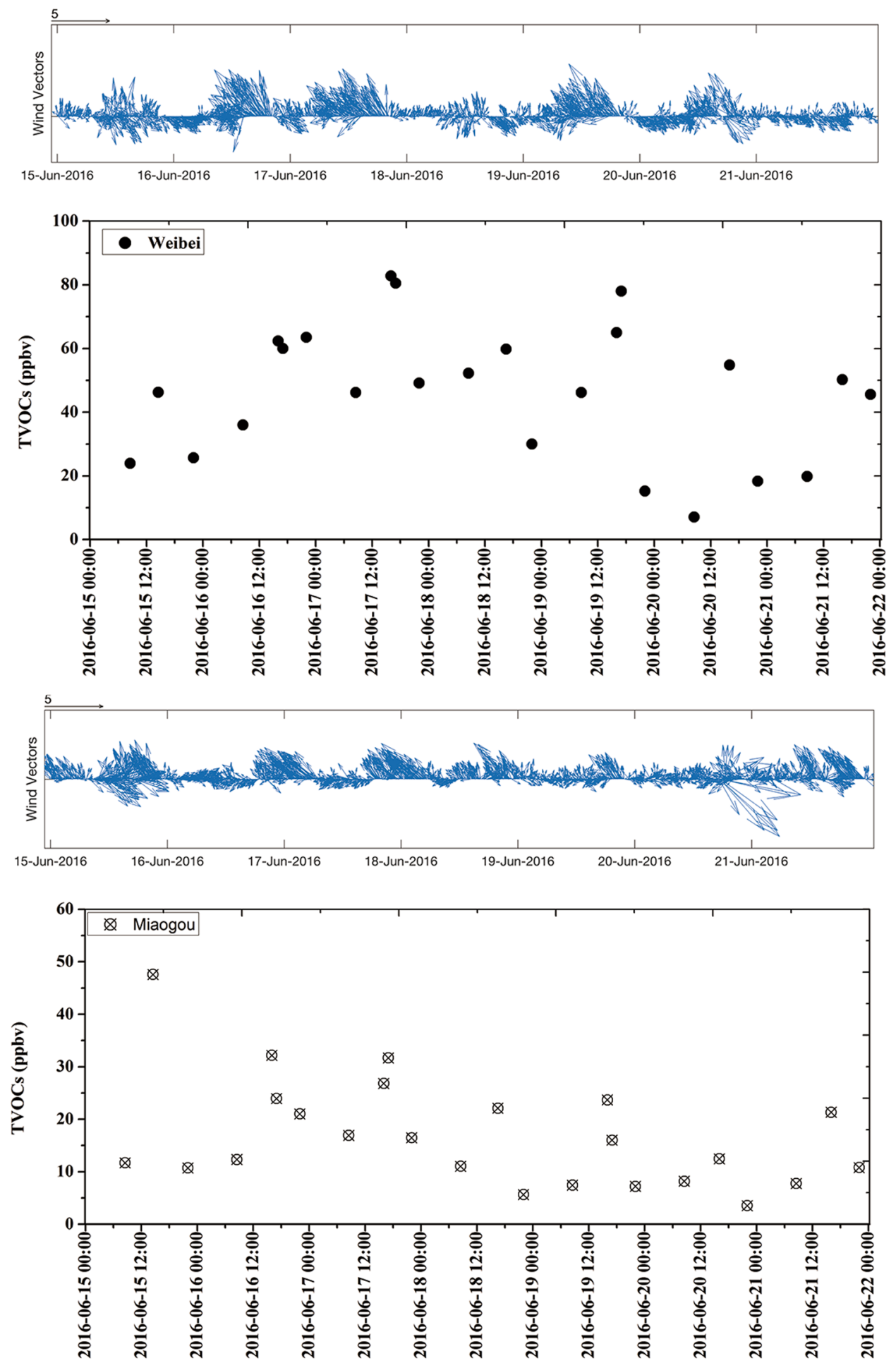

Figure 1. Temporal variations of TVOCs (sum of VOCs PAMS $_{\text {) }}$ with surface wind direction in Weibin site and Miaogou.

that high contribution of vegetation, isoprene is identified as a biogenic source marker. Factor 7 can be identified as biogenic source since isoprene had the highest contribution ${ }^{10}$.

Taking all of the samples in accounting, vehicle exhaust (44.5\%), industrial discharges (20.1\%), and solvent

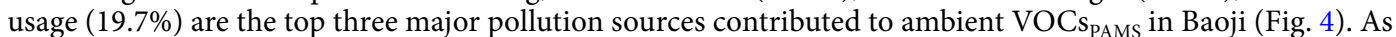
mentioned above, Baoji is a typical industrial city, and the main industries include power plants, coal chemical industry, metal smelting, and coke productions ${ }^{36}$. Most of the related industries use coal as fuel or feed, this could cause high level of benzene in ambient air. In addition, heavy industries induce dense heavy truck usage for transport in the city Baoji. These together makes high contribution of industrial and diesel vehicle exhaust. 

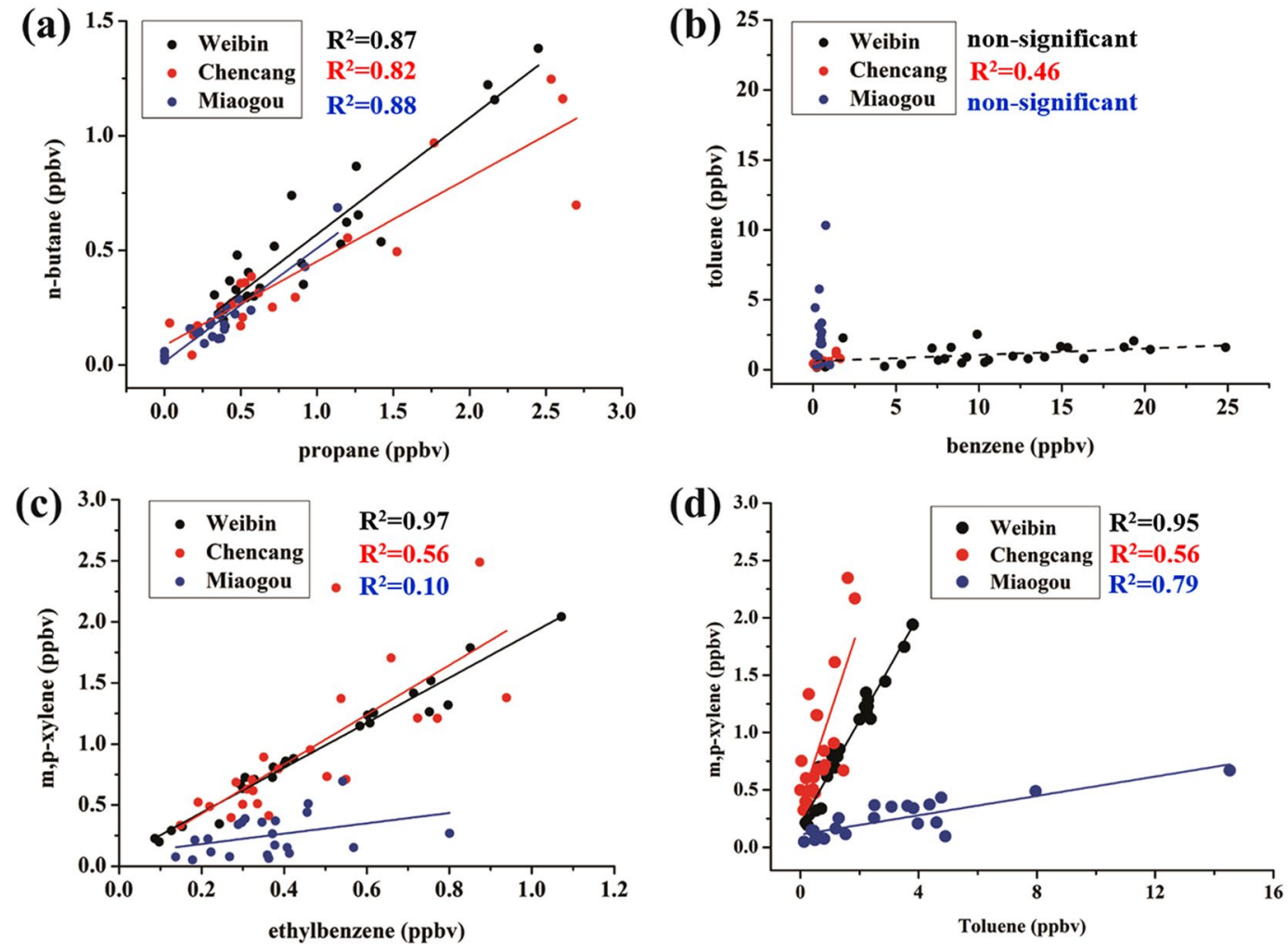

Figure 2. Regression plots between of VOCs species at Weibin, Chencang and Miaogou sites of Baoji.

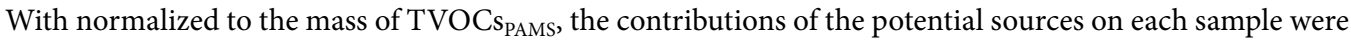
obtained, and their strengths were compared by taking the mean values at the different sites (Table S3). The

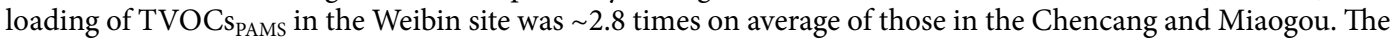
industry emission and gasoline-related sources were the two largest contributors ( $37.9 \%$ and $29.0 \%$, respectively) in the Weibin site. In the Chencang, diesel exhaust was the most important source, contributing to $59.4 \%$ of the TVOCs $_{\text {PAMS }}$. Solvent-related emission contributed $36.7 \%$ of TVOCs PAMS $_{\text {in }}$ the Miaogou due to trace commercial painting activities. Covering with a high density of forest area, the mixing ratio of isoprene at the Miaogou was high. Therefore, a stronger strength of biogenic emission of $13.3 \%$ was found, in comparison with only 5.1 and $7.1 \%$ at the Weibin site and Chencang, respectively.

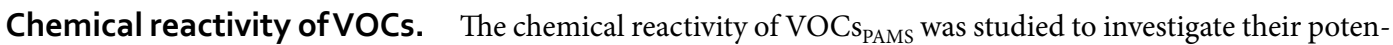
tial oxidation ability with $\mathrm{OH}^{\bullet}$, which can consequently lead the formation of surface $\mathrm{O}_{3}{ }^{7}$. The sum of $\mathrm{OH}^{\bullet}$ loss rate $\left(\mathrm{L}_{\mathrm{OH}}\right)$ was calculated on basis of reaction rate constant between an individual $\mathrm{VOCs}_{\mathrm{PAMS}}$ and $\mathrm{OH}^{\bullet}$ and its

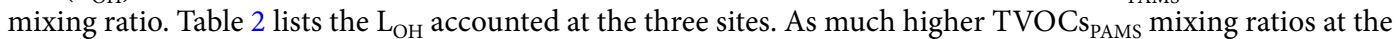
Weibin site, higher $\mathrm{L}_{\mathrm{OH}}\left(27.20 \pm 12.55 \mathrm{~s}^{-1}\right)$ was obtained in comparison of those at other two sampling sites. The $\mathrm{L}_{\mathrm{OH}}$ in Weibin site was mainly dominated by the groups of alkenes and aromatics due to the strong influences of industrial and traffic emissions. In addition to their high chemical reactivity, the two pollution sources are thus considered to play key roles on hydroxyl radical-driven oxidations in Weibin site Baoji. The air quality at the Chencang was less impacted by the direct industrial activities, and the $\mathrm{L}_{\mathrm{OH}}$ was thus less than half of that in the Weibin site. The group of alkanes, which has a lower chemical reactivity, was the major contributor (35.6\%) to

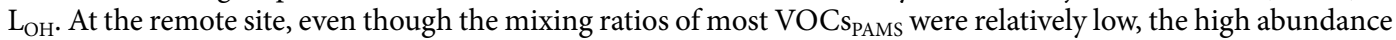
of extremely-reactive isoprene dominated $32.5 \%$ to $\mathrm{L}_{\mathrm{OH}}$, resulting of an equivalent level of oxidation potential as that accounted in the Chencang.

Considering that alkenes play important roles on the chemical reactivity, the contributions of the most significant individuals at different concentration levels were displaced in Fig. 5. At a low mixing ratio region (0-35 ppbv), mostly in samples collected in the Chencang and Miaogou, the biogenic-emitted compounds (i.e., isoprene) showed their dominance and strong strengths to drive the $\mathrm{L}_{\mathrm{OH}}$, while the impacts from anthropogenic sources shrined as a long distance far from the two sites. At a higher mixing ratio of TVOCs PAMS $_{\text {( }}>35 \mathrm{ppbv}$, for the samples collected in the Weibin site), propene and 1-butene were the two most important contributors to $\mathrm{L}_{\mathrm{OH}}$, representing that the industrial and traffic emissions not only can elevate the mixing ratios of VOCs PAMS $_{\text {and }}$ amounts of $\mathrm{OH}$. oxidation, and also lead further surface $\mathrm{O}_{3}$ formation.

Characterization of surface 03. Temporal variation of surface O3. The variations of surface $\mathrm{O}_{3}$ at the three sites were depicted in Fig. 6. The highest $\mathrm{O}_{3}$ concentrations exceeded the national standard in China of $160 \mu \mathrm{g} \mathrm{m}^{-3}$ in the five sampling dates. The diurnal patterns of surface $\mathrm{O}_{3}$ levels were similar at the Weibin site and 

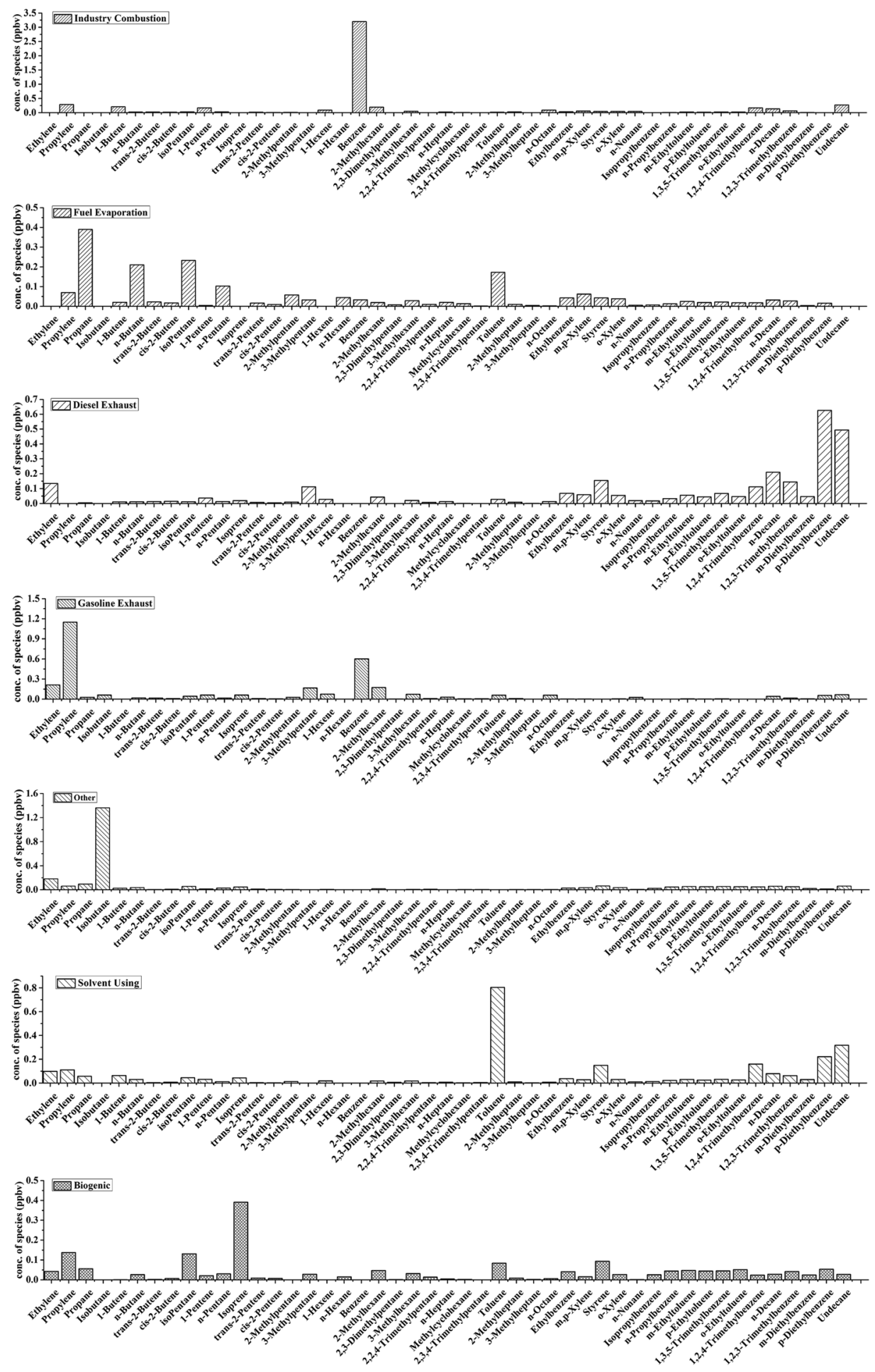

Figure 3. Source profiles obtained from positive matrix factorization model analysis.

Miaogou sites, showing maxima between noon and early evening (Figure S2). In typical, double concentration peaks could be identified during this time interval. The first peak appeared around 13:00, and the next one was recorded between 16:00-17:00. The surface $\mathrm{O}_{3}$ concentrations decreased gradually after 18:00 and the lowest values at the Weibin site and Miaogou sites were often observed at 07:00 and 08:00, respectively. It should be noted that the surface $\mathrm{O}_{3}$ levels were significantly lower at the Weibin site than Miaogou site during the nighttime. The cases have been detailly explained in following sections. 


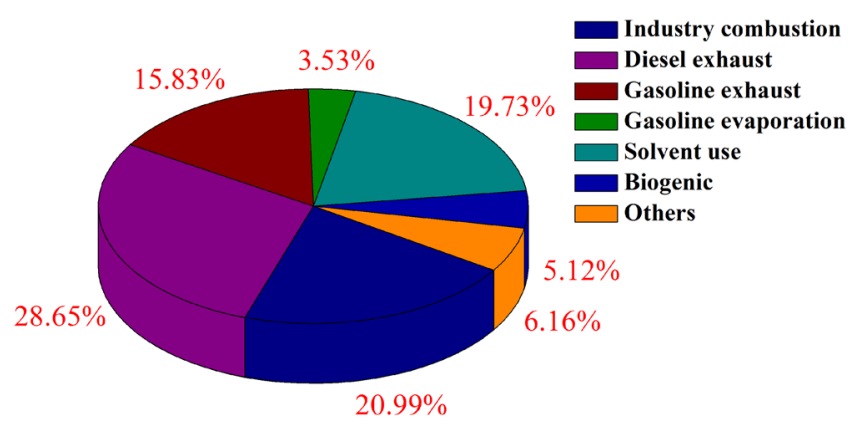

Figure 4. PMF derived average source contributions in Baoji.
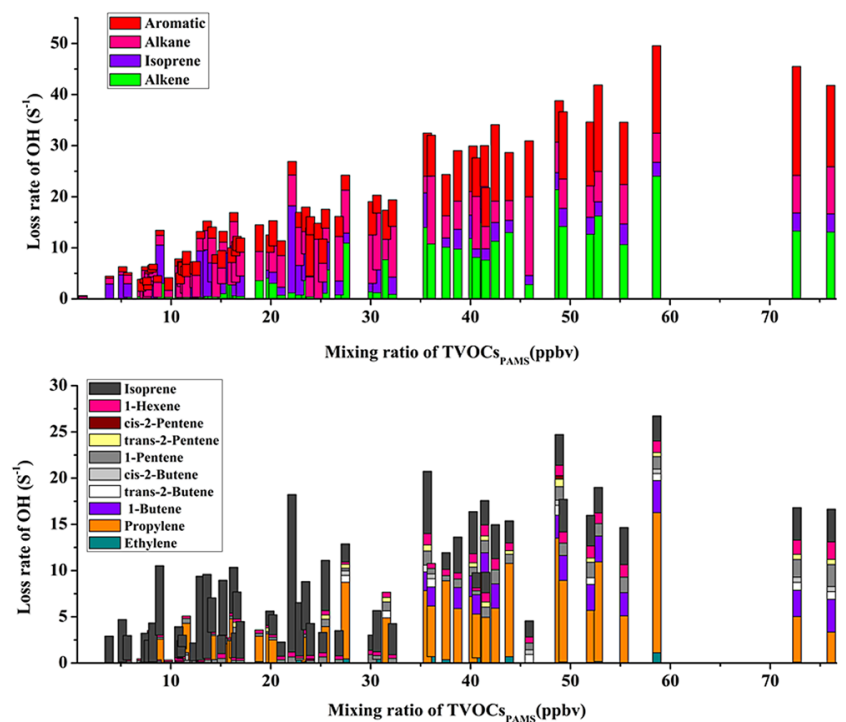

Figure 5. OH radicals loss rates measured with different classes of $\mathrm{VOCs}_{\mathrm{PAMS}}$ (top) and abundant alkenes $\left(\mathrm{C}_{2}-\mathrm{C}_{6}\right.$ alkenes) (bottom) in Baoji as a function of mixing ratio.

\begin{tabular}{|l|l|l|l|l|l|}
\hline \multirow{2}{*}{ Region } & \multirow{5}{*}{$\mathbf{L}_{\mathrm{OH}}\left(\mathbf{S}^{-1}\right)$} & \multicolumn{4}{|l|}{ Composition of VOCs PAMS $_{\mathrm{PA}}(\%)$} \\
\cline { 3 - 6 } & Alkane & Alkene & Aromatic & isoprene \\
\hline Weibin site & $27.20 \pm 12.55$ & 16.8 & $\mathbf{3 7 . 7}$ & 34.6 & 10.9 \\
\hline Chencang site & $12.21 \pm 6.89$ & $\mathbf{3 5 . 6}$ & 19.6 & 27.1 & 11.2 \\
\hline Miaogou site & $11.89 \pm 8.25$ & $\mathbf{3 9 . 7}$ & 10.8 & 19.6 & 32.5 \\
\hline
\end{tabular}

Table 2. Estimated $\mathrm{OH}$ radical loss rates with VOCs PAMS. $_{\text {. }}$.

Influences from meteorological conditions. The correlations between surface $\mathrm{O}_{3}$ and important meteorological parameters were fully studied. High $\mathrm{O}_{3}$ concentrations were often detected under high ambient temperatures and low RHs, which offer favor conditions for either formation or reservation of $\mathrm{O}_{3}{ }^{50,51}$. In the current study, the $\mathrm{O}_{3}$ values were positively correlated to the temperature in both of the Weibin site $\left(\mathrm{R}^{2}=0.59\right)$ and Miaogou $\left(\mathrm{R}^{2}=0.61\right)$ during daytime, when associated with higher light intensity and radiations. Besides, water vapor could scavenge $\mathrm{O}_{3}$ and its precursors in atmosphere by wet deposition ${ }^{52}$. As expected, the surface $\mathrm{O}_{3}$ levels was found to be negatively correlated with RHs at Weibin site $\left(\mathrm{R}^{2}=0.46\right)$ and Miaogou $\left(\mathrm{R}^{2}=0.51\right)$ sites.

The $\mathrm{O}_{3}$ levels were also coincided with the surface zonal winds within our observation period (Fig. 6$)^{3,53}$. In the Weibin site, higher surface $\mathrm{O}_{3}$ concentrations were often seen in accordance of strong easterly wind, consist-

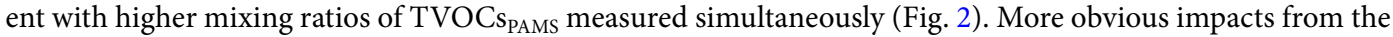
direction of surface winds could be seen at the Miaogou site. Five episodes were defined between Jun 16 and Jun 20 , when the $\mathrm{O}_{3}$ levels increased with easterly winds and under higher ambient temperatures. Particularly, the double $\mathrm{O}_{3}$ peaks occurred in the afternoon on Jun 16, Jun 17 and Jun 19, while strong northeasterly and northerly winds were dominated. This suggested that the polluted air masses were transported from the Weibin site and industrial zone in the northeastern region of Baoji. Xue et al. ${ }^{3}$ investigated a variety of pollution origins on the 


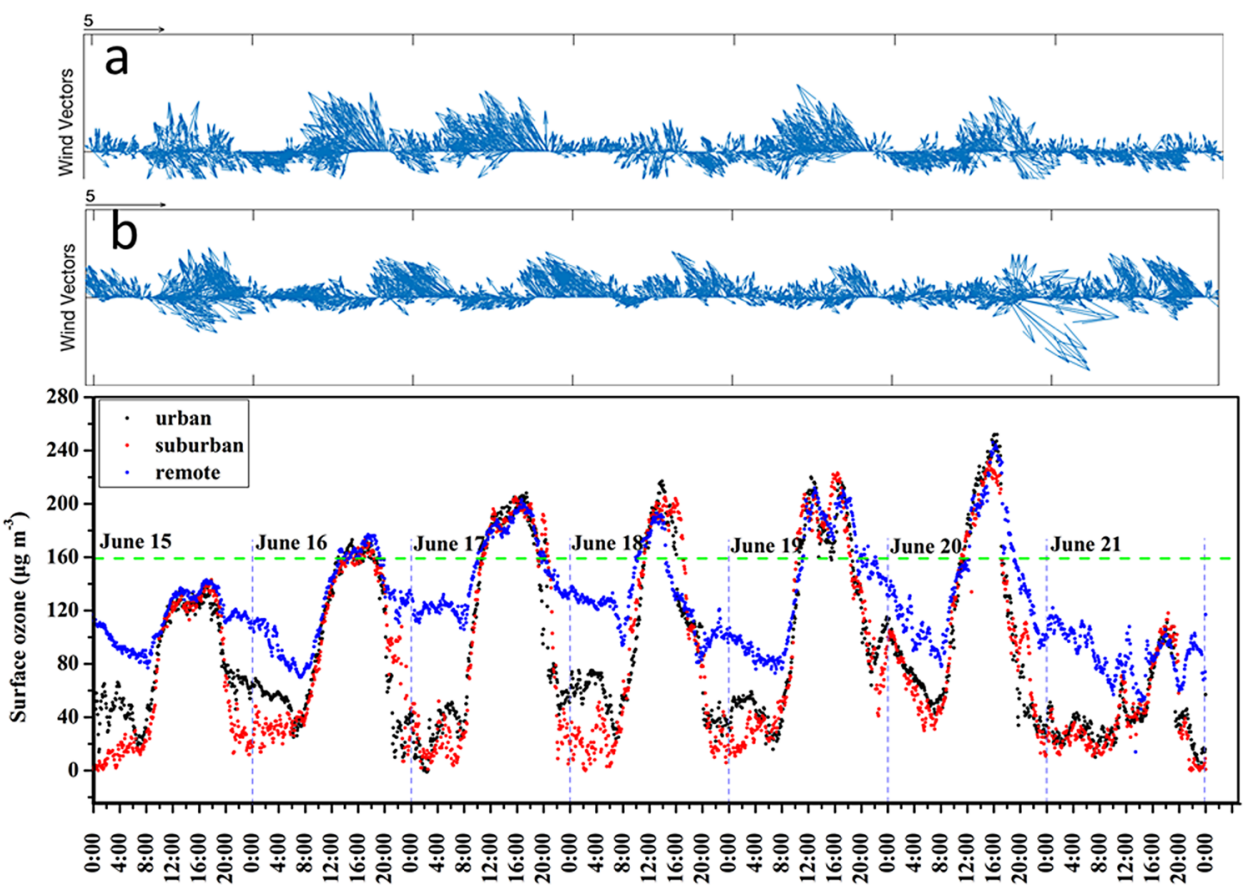

Figure 6. Temporal variation of surface ozone among the sampling time.

formation of $\mathrm{O}_{3}$, and concluded that the surface $\mathrm{O}_{3}$ level in the Miaogou area was dominantly impacted by the exports from the well-processed industrial plumes. The results of our study were consistent with the findings. The first $\mathrm{O}_{3}$ peak in the afternoon was reasonably initiated by the formations from the local pollutants (i.e., photochemically reactive of isoprene emitted from biogenic sources), while the second peak could be resulted by the transportation of the industrial plume with high VOCs emission from the upwind locations.

Ozone formation potential. While $\mathrm{L}_{\mathrm{OH}}$ was used to assess the VOCs activities, ozone formation potential (OFP) could be more direct method to measure the contributions of $\mathrm{VOCs}_{\text {PAMS }}$ in the $\mathrm{O}_{3}$ formation ${ }^{8,54}$. Ozone formation potential (OFP) were calculated based on the average mixing ratios and the maximum incremental

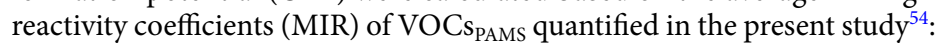

$$
\mathrm{OFP}_{\mathrm{i}}=\mathrm{MIR}_{\mathrm{i}} \times \mathrm{C}_{\mathrm{i}}
$$

where $\mathrm{C}_{\mathrm{i}}$, represents the mixing ratio (ppbv) for species $i$. The MIRs were obtained from Carter $^{54}$. The estimated OFP for the top 20 contributors were given in Table 3. The highest overall OFP (185.36 ppbv on average) was accounted in the Weibin site, in comparison of 42.89 and $56.74 \mathrm{ppbv}$ at the Miaogou and Chencang sites, respectively. The contributions of each VOCs PAMS to overall OFP varied from the sites, that might be driven by their degrees of degradation and dilution in transportation processes ${ }^{48}$. In the Weibin site, alkenes and aromatics were dominated and totally contributed $>90 \%$ of the overall OFP loading. The marker species of propene and

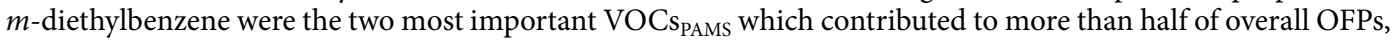
indicating that vehicle and industrial emissions greatly affected the surface $\mathrm{O}_{3}$ formation. At the Miaogou site, isoprene and solvent-characterized VOCs such as toluene, styrene, xylenes, and long-chain alkanes contributed most of OFPs loading. In another aspect, air mass aging can also contribute the variation of $\mathrm{OFPs}^{28}$. Even though the overall estimated OFPs was low at the Miaogou site, the actual $\mathrm{O}_{3}$ levels were not the lowest as expected (Fig. 6). This can be ascribed to the transport of $\mathrm{O}_{3}$ from other upwind districts ${ }^{3}$. The results from the current study concluded that the fresh plume from industrial and traffic sources at the upwind location could highly impact on the air quality in Baoji, and lead the occurrence of $\mathrm{O}_{3}$ episodes in residential areas in summer.

\section{Conclusions}

Ozone pollution control is a challenging task in China, partly due to a huge number of VOCs emissions. In this study, the high levels and compositions of alkenes and aromatics in the the ambient of Baoji suggest the large contributions from the combustion sources in surrounding industries. The temporal variations of VOCs PAMS $_{\text {were }}$ driven by the directions of surface winds, in which the pollutants were transported from upwind regions. Aging of air mass was much obviously at the Miaogou site owing to its location distanced from the dense pollution origins. The $\mathrm{O}_{3}$ formation in Baoji was influenced by both export of well-processed industry plume and photochemical reactions. More long-term VOCs monitoring and environmental assessment are thus needed to interpret the characteristic roles of VOCs in the production of surface $\mathrm{O}_{3}$ in different regions in China. Development of mathematical models is vital to conclude the data in assistance to solve the related environmental issue. 


\begin{tabular}{|c|c|c|c|c|c|c|c|c|}
\hline \multicolumn{3}{|l|}{ Weibin site } & \multicolumn{3}{|l|}{ Miaogou Site } & \multicolumn{3}{|l|}{ Chencang Site } \\
\hline & Average & STDEV & & Average & STDEV & & Average & STDEV \\
\hline Alkanes & 13.63 & 6.72 & Alkanes & 6.42 & 3.65 & Alkanes & 8.34 & 4.42 \\
\hline Alkenes & 82.13 & 40.57 & Alkenes & 17.26 & 18.03 & Alkenes & 21.35 & 24.01 \\
\hline Aromatics & 89.60 & 50.24 & Aromatics & 19.21 & 14.60 & Aromatics & 27.05 & 17.84 \\
\hline m-diethylbenzene & 54.67 & 39.88 & isoprene & 8.13 & 7.09 & propylene & 12.74 & 18.04 \\
\hline propylene & 50.60 & 30.74 & toluene & 7.70 & 9.12 & m,p-xylene & 8.15 & 4.91 \\
\hline 1-butene & 9.53 & 8.82 & propylene & 4.96 & 11.51 & 1,2,4-trimethylbenzene & 4.04 & 3.31 \\
\hline $\mathrm{m}, \mathrm{p}-X_{\text {Xlene }} \mathrm{a}^{\mathrm{a}}$ & 7.35 & 3.84 & dodecane & 2.06 & 1.56 & isoprene & 3.33 & 4.68 \\
\hline isoprene & 6.25 & 3.46 & m,p-xylene & 1.96 & 1.41 & p-diethylbenzene & 2.95 & 2.59 \\
\hline 1-pentene & 5.17 & 2.21 & p-diethylbenzene & 1.94 & 1.41 & toluene & 2.04 & 1.46 \\
\hline benzene & 4.54 & 2.52 & ethylene & 1.79 & 3.65 & dodecane & 1.97 & 1.89 \\
\hline toluene & 4.09 & 2.67 & styrene & 1.65 & 0.82 & o-xylene & 1.94 & 1.14 \\
\hline 1,2,4-trimethylbenzene & 3.56 & 2.16 & 1,2,4-trimethylbenzene & 1.23 & 1.13 & 1,2,3-trimethylbenzene & 1.70 & 1.46 \\
\hline p-ethyltoluene & 3.25 & 8.55 & 1-pentene & 1.20 & 0.67 & ethylene & 1.56 & 3.49 \\
\hline ethylene & 2.48 & 5.22 & m-diethylbenzene & 0.95 & 1.73 & 1-pentene & 1.53 & 0.93 \\
\hline 1-hexene & 2.44 & 1.21 & ethylbenzene & 0.95 & 0.41 & 1,3,5-trimethylbenzene & 1.50 & 1.21 \\
\hline o-xylene & 2.22 & 1.16 & 1,2,3-trimethylbenzene & 0.84 & 0.71 & ethylbenzene & 1.30 & 0.58 \\
\hline isobutane & 2.21 & 4.04 & cyclopentane & 0.78 & 1.79 & styrene & 1.04 & 0.68 \\
\hline 2-methylhexane & 1.46 & 0.60 & o-xylene & 0.76 & 0.52 & m-ethyltoluene & 0.96 & 0.55 \\
\hline cyclopentane & 1.44 & 4.31 & 1-hexene & 0.60 & 0.41 & isobutane & 0.83 & 1.61 \\
\hline 1,2,3-trimethylbenzene & 1.44 & 1.06 & 1-butene & 0.58 & 2.78 & iso-pentane & 0.71 & 0.47 \\
\hline ethylbenzene & 1.22 & 0.69 & 3-methylpentane & 0.55 & 0.30 & 1-hexene & 0.67 & 0.51 \\
\hline 1,3,5-trimethylbenzene & 1.17 & 0.70 & iso-pentane & 0.46 & 0.26 & 1-butene & 0.65 & 2.92 \\
\hline 3-methylpentane & 1.15 & 0.63 & 2-methylheptane & 0.46 & 0.56 & cyclopentane & 0.58 & 1.57 \\
\hline
\end{tabular}

Table 3. The top 20 most abundant $\mathrm{O}_{3}$ formation potential species measured at the Weibin site, Chencang and Miaogou sites of Baoji (ppbv). ${ }^{a} m$-Xylene and $p$-xylene are co-eluted in the chromatographic separation.

\section{Material and Methods}

Description of sampling sites. Three observation fields managed by the Baoji Municipal Environmental Protection Bureau were selected and categorized as (i) Weibin, (ii) Chencang and (iii) Miaogou, respectively, in this study (Figure S3). The Weibin site (E $\left.107^{\circ} 8^{\prime} 35^{\prime \prime}, \mathrm{N} 34^{\circ} 21^{\prime} 17^{\prime \prime}\right)$ was located in the western part of Baoji city where is at a downwind location of an industrial zone (about $13 \mathrm{~km})$. The Chencang site $\left(\mathrm{E} 107^{\circ} 14^{\prime} 19^{\prime \prime}, \mathrm{N} \mathrm{34^{ \circ }}\right.$ $\left.21^{\prime} 44^{\prime \prime}\right)$ was located at an elementary school in the east of Baoji. No any anthropogenic pollution sources rather

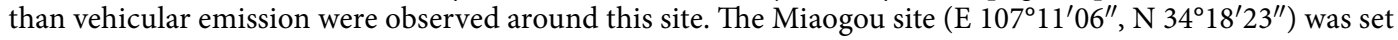
up in the southern Baoji administrative region. The location is surrounded by Qin Mountain where the forests dominated the most land covers. Very scattered factories were found nearby this region. All sampling equipment was set up on the rooftop of the site buildings, which were 10-20 m above the ground.

Field Sampling. Samplings were conducted at 08:00-09:00, 15:00-16:00, 16:00-17:00 and 21:00-22:00, respectively, from June 15 to June 21,2016 . The VOCs in the air was drawn into a 1/4" o.d. stainless steel multi-bed adsorbent tube filled with Tenax-TA, Carbograph I TD and Carboxen 1003 (C3-DXXX-5266, ca. $380 \mathrm{mg}$ in adsorbent weight per tube, Markes International Ltd., Llantrisant, U.K.) using a low-flow module pump (ACTI-VOC, Markes International Ltd.) at a flow rate of $50 \mathrm{~mL} \mathrm{~min}-1$ for $60 \mathrm{~min}$ (i.e., total sampling volume $=3 \mathrm{~L})$. Insignificant breakthrough $(<5 \%)$ was observed either in field or laboratory demonstration under this sampling flow and volume ${ }^{52}$. Two sorbent tube samples were thus collected in each time interval. The sampling inlet was set-up at $1.5 \mathrm{~m}$ above the ground level. Prior to the sampling, all sorbent tubes were cleaned in a thermal conditioner (TC20, Markes International Ltd.) at $330^{\circ} \mathrm{C}$ for $20 \mathrm{~min}$ before use. All pre-conditioned and sampled tubes were sealed with Difflok caps (Markes International Ltd.) and stored in desiccators at $0^{\circ} \mathrm{C}$ for a maximum of two weeks. The desiccators were filled with silica gel and activated carbon to avoid passive absorption of any water vapor and VOCs, respectively. The pump was calibrated with a mass flow calibrator (Defender 510, Bios, Torrance, CA, USA) before each sampling event. A Teflon filter assembly $(47 \mathrm{~mm}$, Whatman, Clifton, NJ, USA) and a home-made ozone scrubber, manufactured by a $1 \mathrm{~m}$ long and $1 / 4$ " o.d. saturated potassium iodide (KI) coated copper tube, were installed in the air upstream to remove any influences from particulate matter (PM) and $\mathrm{O}_{3}$, respectively. The $\mathrm{O}_{3}$ removal efficiency was $>99 \%$ at a concentration level of 100 ppbv for $60 \mathrm{~min}$ in laboratory test. One field blank was collected on each sampling day. The sorbent samples were properly transported to the laboratory for chemical analysis.

Real-time concentrations of the trace gases were monitored continuously during the sampling event. $\mathrm{NO}_{2} /$ NOx was measured with a chemiluminescence detector (Model 42i, Thermo Electron, Waltham, MA, USA), and surface $\mathrm{O}_{3}$ was monitored with an ultra-violet (UV) photometric $\mathrm{O}_{3}$ analyzer (Model 49i, Thermo Electon). The time resolution for these instruments was $5 \mathrm{~min}$ and the minimum detection limit (MDL) for both $\mathrm{NO}_{2} / \mathrm{NOx}$ and 
$\mathrm{O}_{3}$ were 0.5 ppbv. The meteorological data (i.e., temperature, wind speed/direction and Relative Humidity) were recorded with an multi-parameter automatic weather stations (WXT520, Vaisala).

Chemical Analysis. A total of 72 valid sorbent tube samples were collected. They were all analyzed using a thermal desorption (TD) unit (Series 2 UNITY-xr system, Markes International Ltd.) coupled with a gas chromatograph/mass spectrometric detector (GC/MSD, Models 7890 A/5977B, Agilent, Santa Clara, CA, USA) within one week. The chemical analysis procedure can be found in our previous work ${ }^{55}$. A tube was connected into the TD unit at room temperature $\left(\sim 25^{\circ} \mathrm{C}\right)$ and purged with ultra-high purity (UHP) helium (He) gas at a flow rate of $40 \mathrm{~mL} \mathrm{~min}-1$ for $60 \mathrm{~s}$ to eliminate air and oxygen intrusion. For the primary desorption stage, the analytes were desorbed at $330^{\circ} \mathrm{C}$ for $5 \mathrm{~min}$ and refocused onto a cryogenic-trap (U-T1703P-2S, Markes International Ltd.) to capture high volatility target compounds at $-15^{\circ} \mathrm{C}$. For the secondary desorption stage, the trap was dry-purged for $6 \mathrm{~s}$ and rapidly heated from $-15^{\circ} \mathrm{C}$ to $320^{\circ} \mathrm{C}$ and maintained for $5 \mathrm{~min}$. The analytes were passed via a heated transfer line at $160^{\circ} \mathrm{C}$, and re-refocused onto a cold GC capillary column head (Rtx ${ }^{\circledR}-1,105 \mathrm{~m} \times 0.25 \mathrm{~mm} \times 1 \mu \mathrm{m}$ film thickness, Restek Corporation, Bellefonte, PA, USA) at $-45^{\circ} \mathrm{C}$ with an aid of liquid nitrogen $\left(\mathrm{N}_{2}\right)$ in $\mathrm{GC}$ oven. Once the second desorption is completed, the oven temperature program started at an initial temperature of $-45^{\circ} \mathrm{C}$ for $4 \mathrm{~min}$, ramped to $230^{\circ} \mathrm{C}$ at a rate of $6^{\circ} \mathrm{C} \mathrm{min}^{-1}$, and maintained at $230^{\circ} \mathrm{C}$ for $5 \mathrm{~min}$. The constant flow rate of He carrier gas was $1.0 \mathrm{~mL} \mathrm{~min}^{-1}$ throughout the GC analysis. The MSD was operated in selective ion monitoring (SIM) mode at $230^{\circ} \mathrm{C}$ and $70 \mathrm{eV}$ for electron ionization. Identification was achieved by comparing the mass spectra and retention times of the chromatographic peaks with those authentic standards. Certified PAMS standard mixtures (Restek Corporation) were used in calibrations. A multi-point calibration curve was established to quantify each of the target compounds with linearity $>0.999$. The minimum detection limits (MDLs) were in the range of $0.003-0.808 \mathrm{ppbv}$ with a sampling volume of $3 \mathrm{~L}$. The measurement precision for the analysis of eight replicates of standard samples at 2 ppbv were $\leq 5 \%$.

Method for Source apportionment. A standard receptor model of PMF (Version 3.0) recommended by U.S.EPA was used for source apportionment in this study. In principle, the PMF model is based on the following equations:

$$
\begin{gathered}
x_{i j}=\sum_{k=1}^{p} g_{i k} f_{k j}+e_{i j} \\
Q=\sum_{t=1 j=1}^{n} \sum^{m}\left[\frac{x_{i j}-\sum_{k=1}^{p} g_{i k} f_{k j}}{\mu_{i j}}\right]^{2} \\
U=\sqrt{(E F \times \text { conc })^{2}+(M D L)^{2}}(\operatorname{conc}>M D L)
\end{gathered}
$$

where $x_{i j}$ is the concentration of the jth congener in the ith sample of the original data sets; $g_{i k}$ is the contribution of the kth factor to the ith sample; $f_{k j}$ is the fraction of the kth factor arising from congener $j ; e_{i j}$ is the residual between the measured $\mathrm{X}_{\mathrm{ij}}$ and the predicted $\mathrm{X}_{\mathrm{ij}}$ using $\mathrm{p}$ principal components. $\mu_{\mathrm{ij}}$ is the uncertainty of the jth congener in the ith sample of the original data sets containing $m$ congener and $n$ samples. $Q$ is the weighted sum of squares of differences between the PMF output and the original data sets. One of the objectives of PMF analysis is to minimize the $\mathrm{Q}$ value.

\section{References}

1. Chan, C. Y. et al. Characteristics of biomass burning emission sources, transport, and chemical speciation in enhanced springtime tropospheric ozone profile over Hong Kong. J. Geophys. Res. Atmos. 108, 2156-2202 (2003).

2. Stohl, A. et al. Stratosphere-troposphere exchange: A review, and what we have learned from STACCATO. J. Geophys. Res. Atmos. 108, $8516(2003)$

3. Xue, L. K. et al. Ground-level ozone in four Chinese cities: precursors, regional transport and heterogeneous processes. Atmos. Chem. Phys. 14, 13175-13188 (2014).

4. Sillman, S. et al. The relation between ozone, NOx and hydrocarbons in urban and polluted rural environments. Atmos. Environ. 33, 1821-1845 (1999).

5. Brune, W. H. et al. Ozone production chemistry in the presence of urban plumes. Faraday Discussions. 189, 169-189 (2016).

6. Xue, L. K. et al. Sources and photochemistry of volatile organic compounds in the remote atmosphere of western China: results from the Mt. Waliguan Observatory. Atmos. Chem. Phys. 13, 8551-8567 (2013).

7. Shao, M. et al. Volatile organic compounds measured in summer in Beijing and their role in ground-level ozone formation. J. Geophys. Res. Atmos. 114, D00G06 (2009).

8. Zou, Y. et al. Characteristics of 1 year of observational data of VOCs, $\mathrm{NOx}$ and $\mathrm{O}_{3}$ at a suburban site in Guangzhou, China. Atmos. Chem. Phys. 15, 6625-6636 (2015).

9. Ou, J. et al. Ambient Ozone Control in a Photochemically Active Region: Short-Term Despiking or Long-Term Attainment? Environ. Sci. Technol. 50, 5720-5728 (2016).

10. Liu, Y. et al. Source profiles of volatile organic compounds (VOCs) measured in China: Part I. Atmos. Environ. 42, 6247-6260 (2008).

11. Yuan, B., Liu, Y., Shao, M., Lu, S. \& Streets, D. G. Biomass Burning Contributions to Ambient VOCs Species at a Receptor Site in the Pearl River Delta (PRD), China. Environ. Sci. Technol. 44, 4577-4582 (2010).

12. Chin, J. Y. \& Batterman, S. A. VOC composition of current motor vehicle fuels and vapors, and collinearity analyses for receptor modeling. Chemosphere. 86, 951-958 (2012).

13. Zhang, Y. et al. Species profiles and normalized reactivity of volatile organic compounds from gasoline evaporation in China. Atmos. Environ. 79, 110-118 (2013).

14. Wang, H. et al. Source Profiles and Chemical Reactivity of Volatile Organic Compounds from Solvent Use in Shanghai, China. Aerosol. Air. Qual. Res. 14, 301-310 (2014). 
15. Wei, W., Cheng, S., Li, G., Wang, G. \& Wang, H. Characteristics of volatile organic compounds (VOCs) emitted from a petroleum refinery in Beijing, China. Atmos. Environ. 89, 358-366 (2014).

16. Zheng, J. et al. Industrial sector-based volatile organic compound (VOC) source profiles measured in manufacturing facilities in the Pearl River Delta, China. Sci. Total Environ. 456, 127-136 (2013).

17. Stavrakou, T. et al. Substantial Underestimation of Post-Harvest Burning Emissions in the North China Plain Revealed by MultiSpecies Space Observations. Sci. Rep. 6, 32307 (2016).

18. Guenther, A. et al. A global model of natural volatile organic compound emissions. J. Geophys. Res. Atmos. 100, 8873-8892 (1995).

19. Guenther, A. et al. Estimates of global terrestrial isoprene emissions using MEGAN (Model of Emissions of Gases and Aerosols from Nature). Atmos. Chem. Phys. 6, 3181-3210 (2006).

20. Zenone, T. et al. Interaction between isoprene and ozone fluxes in a poplar plantation and its impact on air quality at the European level. Sci. Rep. 6, 32676 (2016).

21. Song, Y. et al. Source Apportionment of Ambient Volatile Organic Compounds in Beijing. Environ. Sci. Technol. 41, 4348-4353 (2007).

22. Ling, Z. H., Guo, H., Cheng, H. R. \& Yu, Y. F. Sources of ambient volatile organic compounds and their contributions to photochemical ozone formation at a site in the Pearl River Delta, southern China. Environ. Pollut. 159, 2310-2319 (2011).

23. Huang, Y. et al. Characterization of volatile organic compounds at a roadside environment in Hong Kong: An investigation of influences after air pollution control strategies. Atmos. Environ. 122, 809-818 (2015).

24. Song, Y. et al. Comparison of receptor models for source apportionment of volatile organic compounds in Beijing, China. Environ. Pollut. 156, 174-183 (2008)

25. Yuan, Z. et al. Source analysis of volatile organic compounds by positive matrix factorization in urban and rural environments in Beijing. J. Geophys. Res. Atmos. 114, D00G15 (2009).

26. Li, B. et al. Characterizations of volatile organic compounds (VOCs) from vehicular emissions at roadside environment: The first comprehensive study in Northwestern China. Atmos. Environ. 161, 1-12 (2017).

27. Liu, Y. et al. Source apportionment of ambient volatile organic compounds in the Pearl River Delta, China: Part II. Atmos. Environ. 42, 6261-6274 (2008).

28. Yuan, B. et al. Volatile organic compounds (VOCs) in urban air: How chemistry affects the interpretation of positive matrix factorization (PMF) analysis. J. Geophys. Res. Atmos. 117, D24302 (2012).

29. Guo, S. et al. Elucidating severe urban haze formation in China. P. Natl. Acad. Sci. USA. 111, 17373-17378 (2014).

30. Huang, R. J. et al. High secondary aerosol contribution to particulate pollution during haze events in China. Nature. 514, 218-222 (2014).

31. Li, L., Xie, S., Zeng, L., Wu, R. \& Li, J. Characteristics of volatile organic compounds and their role in ground-level ozone formation in the Beijing-Tianjin-Hebei region, China. Atmos. Environ. 113, 247-254 (2015).

32. Ma, Z. et al. Significant increase of surface ozone at a rural site, north of eastern China. Atmos. Chem. Phys. 16, 3969-3977 (2016).

33. Wang, T. et al. Increasing surface ozone concentrations in the background atmosphere of Southern China, 1994-2007. Atmos. Chem. Phys. 9, 6217-6227 (2009)

34. Lee, Y. C. et al. Increase of ozone concentrations, its temperature sensitivity and the precursor factor in South China. TELLUS. B. 66, 23455 (2014).

35. Tang, G. et al. Surface ozone trend details and interpretations in Beijing, 2001-2006. Atmos. Chem. Phys. 9, 8813-8823 (2009).

36. Lu, X., Wang, L., Lei, K., Huang, J. \& Zhai, Y. Contamination assessment of copper, lead, zinc, manganese and nickel in street dust of Baoji, NW China. J. Hazard Mater. 161, 1058-1062 (2009).

37. Sexton, K. \& Westberg, H. Ambient hydrocarbon and ozone measurements downwind of a large automotive painting plant. Environ. Sci. Technol. 14, 329-332 (1980).

38. Sillman, S., Logan, J. A. \& Wofsy, S. C. The sensitivity of ozone to nitrogen oxides and hydrocarbons in regional ozone episodes. J. Geophys. Res. Atmos. 95, 1837-1851 (1990).

39. Ryerson, T. B. et al. Observations of Ozone Formation in Power Plant Plumes and Implications for Ozone Control Strategies. Science. 292, 719-723 (2001).

40. Jia, C. et al. Non-methane hydrocarbons (NMHCs) and their contribution to ozone formation potential in a petrochemical industrialized city, Northwest China. Atmos. Res. 169, 225-236 (2016).

41. USEPA. Photochemical Assessment Monitoring Stations (PAMS). (2016).

42. Zhang, Z. et al. Ambient air benzene at background sites in China's most developed coastal regions: Exposure levels, source implications and health risks. Sci. Total Environ. 511, 792-800 (2015).

43. Yuan, B., Shao, M., Lu, S. \& Wang, B. Source profiles of volatile organic compounds associated with solvent use in Beijing, China. Atmos. Environ. 44, 1919-1926 (2010).

44. Chattopadhyay, G., Chatterjee, S. \& Chakraborti, D. Determination of Benzene, Toluene and Xylene in Ambient Air Inside Three Major Steel Plant Airsheds and Surrounding Residential Areas. Environ. Technol. 17, 477-488 (1996).

45. Fan, R. et al. Biomass fuels and coke plants are important sources of human exposure to polycyclic aromatic hydrocarbons, benzene and toluene. Environ. Res. 135, 1-8 (2014).

46. Halliday, H. S. et al. Atmospheric benzene observations from oil and gas production in the Denver-Julesburg Basin in July and August 2014. J. Geophys. Res. Atmos. 121(11), 055-011,074 (2016).

47. Lee, S. C., Chiu, M. Y., Ho, K. F., Zou, S. C. \& Wang, X. Volatile organic compounds (VOCs) in urban atmosphere of Hong Kong. Chemosphere. 48, 375-382 (2002).

48. Ho, K. F., Lee, S. C., Guo, H. \& Tsai, W. Y. Seasonal and diurnal variations of volatile organic compounds (VOCs) in the atmosphere of Hong Kong. Sci. Total Environ. 322, 155-166 (2004).

49. Perring, A. E., Pusede, S. E. \& Cohen, R. C. An Observational Perspective on the Atmospheric Impacts of Alkyl and Multifunctional Nitrates on Ozone and Secondary Organic Aerosol. Chem. Rev. 113, 5848-5870 (2013).

50. Lou, T. M., Reynolds., J., Cox, L. H., Guttorp, P. \& Sampson, P. D. A review of statistical methods for the meteorological adjustment of tropospheric ozone. Atmos. Environ. 35, 617-630 (2001).

51. Wang, X. et al. Characteristics of surface ozone at an urban site of Xi'an in Northwest China. J. Environ. Monitor. 14, 116-126 (2012).

52. Tu, J., Xia, Z. G., Wang, H. \& Li, W. Temporal variations in surface ozone and its precursors and meteorological effects at an urban site in China. Atmos. Res. 85, 310-337 (2007).

53. Reddy, P. J. \& Pfister, G. G. Meteorological factors contributing to the interannual variability of midsummer surface ozone in Colorado, Utah, and other western U.S. states. J. Geophys. Res. Atmos. 121, 2434-2456 (2016).

54. Carter, W. P. L. Development of Ozone Reactivity Scales for Volatile Organic Compounds. J. Air Waste Manage. 44, 881-899 (1994).

55. Ho, S. S. H. et al. Influences of relative humidities and temperatures on the collection of C2-C5 aliphatic hydrocarbons with multibed (Tenax TA, Carbograph 1TD, Carboxen 1003) sorbent tube method. Atmos. Environ. 151, 45-51 (2017). 


\section{Acknowledgements}

This research was financially supported by the National Key Research and Development Program of China (2016YFA0203000), the National Science Foundation of China $(41401567,41573138,41503117)$, and the Key Project of International Cooperation of the Chinese Academy of Sciences (GJHZ1543), and "Strategic Priority Research Program" of the Chinese Academy of Sciences, Grant No. XDB05060500. Yu Huang is also supported by the "Hun-dred Talent Program" of the Chinese Academy of Sciences.

\section{Author Contributions}

Yu Huang and Yonggang Xue conceived and designed the study. Bowei Li, Wenting Dai and Liqin Wang conducted the samples collection, experiments and data analysis. Steven Sai Hang Ho, Junji Cao, and Shuncheng Lee assisted in data analysis and manuscript preparation. Yonggang Xue wrote the manuscript, and all the authors provided comments and feedback on the manuscript.

\section{Additional Information}

Supplementary information accompanies this paper at doi:10.1038/s41598-017-10631-4

Competing Interests: The authors declare that they have no competing interests.

Publisher's note: Springer Nature remains neutral with regard to jurisdictional claims in published maps and institutional affiliations.

(c) (i) Open Access This article is licensed under a Creative Commons Attribution 4.0 International License, which permits use, sharing, adaptation, distribution and reproduction in any medium or format, as long as you give appropriate credit to the original author(s) and the source, provide a link to the Creative Commons license, and indicate if changes were made. The images or other third party material in this article are included in the article's Creative Commons license, unless indicated otherwise in a credit line to the material. If material is not included in the article's Creative Commons license and your intended use is not permitted by statutory regulation or exceeds the permitted use, you will need to obtain permission directly from the copyright holder. To view a copy of this license, visit http://creativecommons.org/licenses/by/4.0/.

(c) The Author(s) 2017 